\title{
Observations on feeding frequencies among native and exotic birds and fruit bats at Erythrina variegata and Dysoxylum trees on American Samoa
}

\author{
Julie A. Sherman \\ School of Geographical Sciences, Arizona State University, Tempe, United States \\ julie.sherman@asu.edu
}

\section{Patricia L. Fall}

School of Geographical Sciences, Arizona State University, Tempe, United States

\section{Introduction}

Like most oceanic islands, Polynesian islands have experienced environmental degradation and native species losses, due in part to deforestation and predation by humans and humanintroduced species (Dahl 1984a, b; Steadman et al. 1999; Cocklin and Keen 2000; Steadman and Martin 2003), as well as natural disturbances such as hurricanes (Craig et al. 1994a; Elmqvist et al. 1994; Pierson et al. 1996; Hjerpe et al. 2001; Whistler 2002; Franklin et al. 2004; McConkey et al. 2004a). Fossil evidence indicates the majority of Polynesian bird and bat species became extinct or were extirpated in the wake of human colonisation (Steadman 1993, 1995, 2006; Koopman and Steadman 1995). Indigenous Polynesian island fruit bats and birds are key pollinators and seed dispersers of native rainforest flora (Fujita and Tuttle 1991; Cox et al. 1991; Rainey et al. 1995; McConkey and Drake 2002; Meehan et al. 2002; Fall et al. 2007). Koopman and Steadman (1995) suggested that a loss of vertebrate frugivores in Polynesia will lead to a decline in plant diversity, and indeed fossil pollen data from Tonga indicate that diminished rainforest plant diversity accompanied the loss of native dispersers and pollinators (Fall 2005). Ancient Polynesian and subsequent European colonists introduced many exotic species now naturalised in the Pacific Islands (Rinke 1986; Wiles et al. 1997; Richardson et al. 2000; Steadman 2006). Introduced fauna prey on or harass native species (Thorsen et al. 2000; Thibault et al. 2002; Blanvillain et al. 2003; Yap and Sodhi 2004), and compete with endemic animals for food (Banko et al. 2002; Hansen et al. 2002). 
American Samoa offers an excellent locale in which to study the ecological implications of exotic wildlife and human habitat modification on Polynesian islands. The human population of American Samoa's main island, Tutuila, is growing, while human habitation on the smaller island of Ofu is decreasing (United States Census Bureau 2001). Human-introduced exotic birds are well established on Tutuila, but have not yet spread to outlying Ofu, Olosega and Ta'u (Watling 2004). Freifeld $(1999,2004)$ has investigated the habitat relationships of avifauna on Tutuila, and there has been considerable research on the feeding behaviour of American Samoa's fruit bats (Banack 1996, 1998; Nelson et al. 2000a, b, 2005; Brooke 2001; Banack and Grant 2002). Few data are available that describe the interactions between exotic and native species at key indigenous nectar sources in American Samoa. We present observations of native and exotic avifauna and fruit bats at indigenous Erythrina variegata and Dysoxylum maoto and Dysoxylum samoensis trees during their peak flowering and fruiting period on Ofu and Tutuila islands, American Samoa. Erythrina nectar and Dysoxylum fruit are important foods for native birds and fruit bats. Limited data are available on feeding frequencies and inter-specific interactions among native and exotic species at Eyrthrina variegata on American Samoa. We observed visitation and feeding by native birds, introduced (exotic) birds and native fruit bats at Erythrina and Dysoxylum trees in native rainforest, rural plantation and native-forest-edge habitats.

\section{American Samoa}

Study sites were located on Tutuila and Ofu islands in American Samoa, part of the Western Polynesian biogeographic subregion (Mueller-Dombois and Fosberg 1998). American Samoa is comprised of five main volcanic islands and two coral atolls located $13-15^{\circ} \mathrm{S}$ and $168-173^{\circ}$ $\mathrm{W}$ in the South Pacific Ocean (Figure 1). The tropical maritime climate here has average daily temperatures between $24^{\circ} \mathrm{C}$ and $30^{\circ} \mathrm{C}$, and rainfall from about $300 \mathrm{~cm}$ to more than $500 \mathrm{~cm}$ annually, with year-round high relative humidity (Western Regional Climate Center 2005). Ofu $\left(5 \mathrm{~km}^{2}\right)$ is characterised by a narrow strip of littoral and lowland rainforest habitats, some of which are used for agriculture. Areas of native forest are most common on steeper slopes and peaks up to $494 \mathrm{~m}$ (Whistler 1994). Ofu's single town has a population of 289 people (United States Census Bureau 2001), a decrease from 353 in 1990 (World Gazetteer 2006). Tutuila has a larger landmass $\left(142 \mathrm{~km}^{2}\right)$ and higher elevations (up to $653 \mathrm{~m}$ ) than Ofu. Tutuila's 55,876 people (United States Census Bureau 2001) and its agricultural lands are concentrated within the littoral and lowland rainforest zones.

\section{Birds and bats of American Samoa}

America Samoa's only native mammals are bats (Banack and Grant 2002). The islands are home to two indigenous species of Pteropodidae (fruit bats): the Tongan fruit bat (Pteropus tonganus) and the Samoan fruit bat (Pteropus samoensis). While both species are vulnerable to human impacts, the Samoan fruit bat has been extirpated on the nearby archipelago of Tonga (Koopman and Steadman 1995), and is endangered in Samoa (Mickleburgh et al. 1992). In 1992, the government of American Samoa banned hunting of all fruit bats to help their populations recover from over-exploitation, as well as from decimation by tropical cyclones in 1987, 1990 and 1991 (Banack 1996).

Native land birds in American Samoa include two honeyeaters: the cardinal honeyeater (Myzomela cardinalis) and the wattled honeyeater (Foulehaio carunculata). Cardinal honeyeaters occur only on Tutuila; they are absent from Ofu (Watling 2004). The sole land bird endemic to Samoa and American Samoa is the Samoan starling (Aplonis atrifusca) (Freifeld 2004). Four pigeons are native to American Samoa: Pacific pigeon (Ducula pacifica), many-coloured fruit 


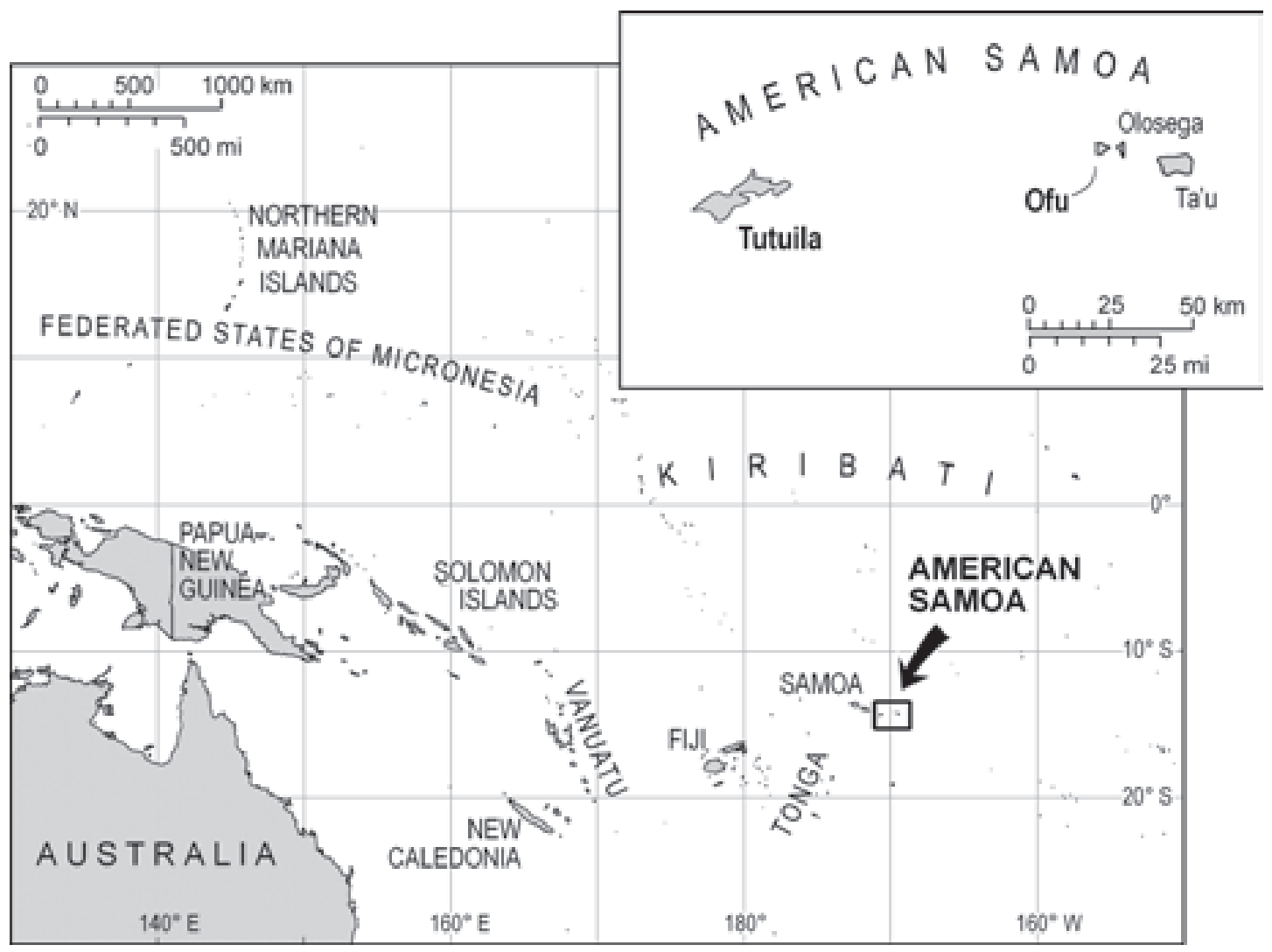

Figure 1. Location of Tutuila and Ofu islands, American Samoa, in the South Pacific. Created by Barbara Trapido-Lurie

dove (Ptilinopus perousii), purple-capped fruit dove (Ptilinopus porphyraceus), and shy ground dove (Gallicolumba stairi) (Steadman and Friefeld 1999). American Samoa banned hunting of all pigeon species in 1992 (Freifeld 2004).

In addition to its native avifauna, American Samoa has been colonised by three exotic, human-introduced bird species: the red-vented bulbul (Pycnonotus cafer bengalensis), the common myna (Acridotheres tristis) and the jungle myna (Acridotheres fuscus) (Freifeld 1999). The red-vented bulbul was introduced into American Samoa in the late 1950s and became established quickly (Freifeld 1999). Bulbuls and mynas are found only on Tutuila. Researchers indicate a need for data regarding behaviour and competition among native birds and exotic bulbuls for native food sources (Freifeld 1999; Watling 2004), and detailing the feeding behaviour of fruit bats at nectar sources (Banack 1998). This study presents data on these matters.

\section{Methods}

We made observations at 16 flowering Erythina variegata and five fruit-bearing Dysoxylum focal trees on Ofu and Tutuila over a 22-day period between 19 July and 9 August 2001 (Table 1). We chose individual and small groups of overlapping trees that provided visibly comparable canopy sizes and food resource availability. In some cases, smaller adjacent trees with overlapping canopies were observed simultaneously, as if they constituted a single tree. Our data were collected at focal trees located in native-forest stands, rural plantations and a transitional native-forest edge. We observed additional, non-focal trees in village and nativeforest habitats for limited periods. Data gathered on feeding or visitations at non-focal trees are included in the discussion. 
Table 1. Erythrina variegata, Dysoxylum maoto and Dysoxylum samoensis focal trees on ofu and Tutuila islands, American Samoa

\begin{tabular}{|c|c|c|c|}
\hline Habitat & Tree & Time range of observations & Total no. of 2-min. intervals \\
\hline \multicolumn{4}{|c|}{ Erythrina variegata trees } \\
\hline \multicolumn{4}{|c|}{ Ofu Island } \\
\hline \multicolumn{4}{|c|}{ Native forest } \\
\hline & E1 & 05:17-07:31 & 158 \\
\hline & E2 & 05:20-07:02 & 131 \\
\hline & E3 & 06:04-07:04 & 31 \\
\hline & E4 & 05:17-07:27 & 119 \\
\hline & E5 & 05:24-06:30 & 41 \\
\hline & E6 & 05:18-07:31 & 101 \\
\hline \multicolumn{4}{|l|}{ Tutuila Island } \\
\hline \multicolumn{4}{|c|}{ Native forest } \\
\hline & E7 & 06:30-07:30 & 43 \\
\hline & E8 & 06:34-07:44 & 47 \\
\hline \multicolumn{4}{|c|}{ Native-forest edge } \\
\hline & E9 & 06:30-08:42 & 57 \\
\hline \multicolumn{4}{|c|}{ Rural plantation } \\
\hline & E10 & 05:50-07:30 & 115 \\
\hline & E11 & 05:50-07:30 & 115 \\
\hline & E12 & 05:54-07:30 & 112 \\
\hline \multicolumn{4}{|c|}{ Dysoxylum maoto and Dysoxylum samoensis trees } \\
\hline \multicolumn{4}{|c|}{ Ofu Island } \\
\hline \multicolumn{4}{|c|}{ Native forest } \\
\hline & D1 & $06: 37-11: 42$ & 106 \\
\hline Habitat & Tree & Time range of observations & Total no. of 2-min. intervals \\
\hline \multicolumn{4}{|l|}{ Tutuila Island } \\
\hline \multicolumn{4}{|c|}{ Native forest } \\
\hline & D2 & 06:30-07:30 & 61 \\
\hline & D3 & 06:34-07:44 & 123 \\
\hline \multicolumn{4}{|c|}{ Rural plantation } \\
\hline & D4 & 05:50-07:30 & 93 \\
\hline
\end{tabular}

Trees E6 and E8 each denote two adjacent trees with overlapping canopies; tree E12 is three adjacent trees with overlapping canopies. Tree D1 denotes two adjacent trees with overlapping canopies. 
Erythrina variegata nectar is an important food for American Samoa's native fruit bats and honeyeaters (Banack 1998; Freifeld 1999; Webb et al. 1999). Dysoxylum maoto and Dysoxylum samoensis provide foods favoured by the native Pacific pigeon (Steadman and Freifeld 1999). Erythrina variegata generally is considered native to American Samoa (e.g. Freifeld 1999), although Whistler (1992) suggests ancient Polynesians may have introduced it to some Pacific Islands, where it has been naturalised for millennia. Erythrina variegata trees flower between July and September (Whistler 1994), when few other trees are flowering (Banack 1998; Webb et al. 1999). Dysoxylum maoto and Dysoxylum samoensis, both indigenous to Samoa (Whistler 1994), are in peak fruit from January through September (Webb et al. 1999).

We recorded visitation and feeding based on scan sampling (Altmann 1974), a method used commonly to assess behaviour of both birds and fruit bats (Pitter and Christiansen 1997; Sun and Moermond 1997; Banack 1998; Ochoa-Acuna and Kunz 1999; Munoz-Romo 2006), as well as to investigate visitation and feeding at focal trees (Boinski and Scott 1988; Tirado Herrera et al. 2003; Kirika et al. 2008). Observations at Erythrina focal trees were made between 05:00 and 09:00 to capture peak feeding times for most avian and fruit-bat species. Although Samoan fruit bats have been observed feeding during all hours of the day, their peak daylight foraging period is between 05:00 and 08:00 (Banack 1996). Daylight activity of the largely nocturnal Tongan fruit bats also peaks between 05:00 and 08:00, and again between 16:00 and 17:59 (Morrell and Craig 1995; Banack and Grant 2002). Our initial observations showed intensive bird feeding at Erythrina during the early morning (06:0008:00), but no evening feeding (17:40-19:00). Thus, we chose to make observations between 05:00 and 09:00, the optimal interval for studying feeding by birds and both species of bats. We collected quantitative data on feeding frequencies over an average period of three days for each tree. Night-vision binoculars were used to observe focal trees before dawn and at dusk. Sunrise during the study period varied between 06:41 and 06:48, with dawn between 06:19 and 06:21. Sunset occurred between 18:07 and 18:16, and dusk continued between 18:30 and 18:38 (United States Naval Observatory 2007). Observations at Dysoxylum trees were made between 05:50 and 12:00, a time range which captures peak activity periods for birds and fruit bats. Data for Dysoxylum samoensis and D. maoto were combined, since these species share a habitat range encompassing primary and secondary coastal and lowland forests (Whistler 1994). Both trees are characterised by alternate, pinnately compound leaves and brown sub-globose fruits (Whistler 1994).

Data were collected at two-minute intervals. At each interval, we recorded the number and species of birds and bats visible in a tree, as well as their behaviour. Aggressive interspecific interactions (e.g. vocalisation and rapid flight in pursuit of an approaching animal) were noted when observed. Feeding was recorded when visible; animals were recorded as perching when engaged in some non-feeding posture in the tree, such as perching, hanging, or preening. Animals flying in or around the focal trees were not recorded. Bird species were identified, while data for Tongan and Samoan fruit bats were combined since often they were indistinguishable in pre-dawn, low-light conditions. We analysed the mean recorded visitation (number) of animals and the mean recorded number of feeding animals at each focal tree. Mean recorded abundance is a common measure to analyse avian habitat relationships (see, for example, Freifeld 1999); we use mean recorded frequencies to present our quantified observations at individual focal trees. 


\section{Results}

We observed cardinal and wattled honeyeaters, red-vented bulbuls and the Tongan and Samoan fruit bats feeding on Erythrina variegata trees. Dysoxylum samoensis and D. maoto trees were visited by the Samoan starlings, Pacific pigeons, wattled honeyeaters, collared kingfishers, common and jungle mynas and the red-vented bulbul (Table 2).

Table 2. Birds and fruit bats observed in Erythrina variegata, Dysoxylum maota and Dysoxylum samoensis trees on Ofu and Tutuila islands, American Samoa. Species origin ( $N=$ native; $E=$ exotic, human-introduced); tree usage shows activity while in tree $(F=$ feeding; $P=$ perching); if feeding, the floral or fruit consumed is noted ( $f r=$ fruit, $s d s=$ seeds, flwrs = flowers, nec $=$ nectar)

\begin{tabular}{|c|c|c|c|c|}
\hline \multicolumn{5}{|c|}{ Erythrina variegata trees } \\
\hline \multicolumn{5}{|l|}{ Birds } \\
\hline$\underline{\text { Scientific name }}$ & $\underline{\text { Common name }}$ & $\underline{\text { Samoan name }}$ & $\underline{\text { Origin }}$ & $\underline{\text { Tree usage }}$ \\
\hline Foulehaio carnunculata & Wattled honeyeater & 'Iao & $\mathrm{N}$ & F, nec \\
\hline Myzomela cardinalis & Cardinal honeyeater & Segasegamau'u & $\mathrm{N}$ & F, nec \\
\hline Pycnonotus cafer & Red-vented bulbul & Manu palagi & $\mathrm{E}$ & F, flwrs, nec \\
\hline \multicolumn{5}{|l|}{ Fruit bats } \\
\hline$\underline{\text { Scientific name }}$ & Common name & $\underline{\text { Samoan name }}$ & Origin & Tree usage \\
\hline Pteropus samoensis & Samoan fruit bat & Pe’a vao & $\mathrm{N}$ & F, flwrs, nec \\
\hline Pteropus tonganus & Tongan fruit bat & Pe’a fanua & $\mathrm{N}$ & F, nec \\
\hline \multicolumn{5}{|c|}{ Dysoxylum maoto and Dysoxylum samoensis trees } \\
\hline \multicolumn{5}{|l|}{ Birds ${ }^{1}$} \\
\hline$\underline{\text { Scientific name }}$ & Common name & $\underline{\text { Samoan name }}$ & Origin & $\underline{\text { Tree usage }}$ \\
\hline Aplonis atrifusca & Samoan starling & Fuia & $\mathrm{N}$ & $\mathrm{F}, \mathrm{fr}, \mathrm{sd} s$ \\
\hline Ducula pacficia & Pacific pigeon & Lupe & $\mathrm{N}$ & $\mathrm{F}, \mathrm{fr}$, sds \\
\hline Foulehaio carnunculata & Wattled honeyeater & 'Iao & $\mathrm{N}$ & $\mathrm{P}$ \\
\hline Halcyon chloris & Collared kingfisher & Tiotala & $\mathrm{N}$ & $\mathrm{P}$ \\
\hline Acridotheres tristis & Common myna & Maina fanua & E & $\mathrm{P}$ \\
\hline Acridotheres fuscus & Jungle myna & Maina vao & E & $\mathrm{P}$ \\
\hline Pycnonotus cafer & Red-vented bulbul & Manu palagi & E & $\mathrm{P}, \mathrm{F}, \mathrm{fr}$ \\
\hline
\end{tabular}

${ }^{1}$ An indigenous columbrid, the many-coloured fruit dove (Ptilinopus perousii Peale), was seen flying by or possibly from the Tutuila Dysoxylum trees, but was not recorded perching or feeding in the trees. Nomenclature, authority and Samoan names follow Utzurrum 2002; Watling 2004; Freifeld 1999; and Steadman 2006.

\section{Erythrina trees}

On both Ofu and Tutuila, all observed birds and bats fed most intensely on Erythrina nectar between 06:30 and 07:30 (Table 3). Cardinal honeyeaters, red-vented bulbuls and fruit bats were not recorded perching in focal trees, although all frequently flew out of trees or to other inflorescences. Honeyeaters arrived and began feeding between 06:07 and 06:44. Red-vented bulbuls followed a similar pattern, with the earliest recorded arrival and feeding at 06:24. Fruit bats were recorded already feeding in Erythrina trees when we arrived before 05:20. By 09:00 there was only very limited bird activity, and bats were generally absent from the trees. Additional observations between 17:40 and 19:00 revealed very limited visitation by any bird or bat species. All observed visitations in this time period involved only perching, and no evening feeding.

We recorded wattled honeyeaters and both Tongan and Samoan fruit bats feeding at Erythrina in Ofu's native forest (Figure 2). Tutuila's wattled and cardinal honeyeaters fed at the highest frequencies at trees in the native forest, where exotic red-vented bulbuls were not observed feeding. Although red-vented bulbuls were not observed feeding in native forests, 
three individuals were recorded in trees adjacent to the road in native forest (near focal trees E7 and E8).

Table 3. Feeding frequencies at Erythrina variegata focal trees on Ofu and Tutuila islands, American Samoa, between 05:00 and 09:00. Data are presented as means (se), indicating the average number of feeding animals per two-minute interval; HE: honeyeater; se: standard error

\begin{tabular}{|c|c|c|c|c|}
\hline & Wattled HE & Cardinal HE & Fruit bats & Bulbuls \\
\hline \multicolumn{5}{|c|}{ Island, Habitat and Tree } \\
\hline \multicolumn{5}{|c|}{ Ofu Island } \\
\hline \multicolumn{5}{|c|}{ Native forest } \\
\hline E1 & $2.47(0.20)$ & 0 & $0.38(0.04)$ & 0 \\
\hline E2 & $2.19(0.18)$ & 0 & $0.63(0.05)$ & 0 \\
\hline E3 & $2.45(0.29)$ & 0 & $0.03(0.03)$ & 0 \\
\hline E4 & $3.52(0.33)$ & 0 & $0.60(0.08)$ & 0 \\
\hline E5 & $1.02(0.25)$ & 0 & $0.61(0.07)$ & 0 \\
\hline E6 & $3.55(0.35)$ & 0 & $0.09(0.03)$ & 0 \\
\hline Sum & $2.72(0.12)$ & 0 & $0.43(0.03)$ & 0 \\
\hline \multicolumn{5}{|c|}{ Tutuila Island } \\
\hline \multicolumn{5}{|c|}{ Native forest } \\
\hline E7 & $4.74(0.26)$ & $0.86(0.16)$ & $0.58(0.13)$ & 0 \\
\hline E8 & $5.30(0.20)$ & $1.47(0.14)$ & $0.57(0.12)$ & 0 \\
\hline Sum & $5.03(0.16)$ & $1.18(0.11)$ & $0.58(0.09)$ & 0 \\
\hline \multicolumn{5}{|c|}{ Native-forest edge } \\
\hline E9 & $2.63(0.14)$ & $0.11(0.05)$ & 0 & $0.32(0.12)$ \\
\hline \multicolumn{5}{|c|}{ Rural plantation } \\
\hline E10 & $0.04(0.02)$ & $0.08(0.04)$ & $1.54(0.06)$ & $5.20(0.41)$ \\
\hline E11 & $0.03(0.02)$ & 0 & $0.82(0.07)$ & $3.90(0.34)$ \\
\hline E12 & $0.04(0.02)$ & $0.18(0.04)$ & $1.70(0.10)$ & $6.61(0.55)$ \\
\hline Sum & $0.04(0.01)$ & $0.08(0.02)$ & $1.35(0.05)$ & $5.23(0.26)$ \\
\hline
\end{tabular}

Trees E6 and E8 each denote two adjacent trees with overlapping canopies; tree E12 is three adjacent trees with overlapping canopies.

On Tutuila's rural plantations, we observed a stark contrast between high feeding frequencies by red-vented bulbuls and very low frequencies for wattled and cardinal honeyeaters (Figure 3). Red-vented bulbuls actively defended focal Erythrina trees and inflorescences from both species of honeyeaters. Many honeyeaters were quickly chased off by bulbuls, which would fly directly at them, vocalising continuously, and pursuing them out of the tree. We observed 43 instances of bulbuls chasing honeyeaters. On only one occasion was a cardinal honeyeater observed chasing a bulbul to another branch. At tree E12 we noted cardinal honeyeaters feeding only at the outer edges of the canopy, away from the central canopy where the bulbuls were concentrated. A focal tree at a native-forest edge in Tutuila (E9) showed substantial feeding by wattled honeyeaters, only modest feeding instances by cardinal honeyeaters and red-vented bulbuls, and no feeding by fruit bats (although Tongan fruit bats were frequently noted feeding at trees in similar habitats). Overall fruit-bat feeding frequency on Tutuila was highest at rural plantation trees. Samoan fruit bats were recorded feeding at native-forest trees, but were not definitively identified at rural plantation trees. Both fruit-bat species were seen feeding at native-forest trees on Tutuila and Ofu. 


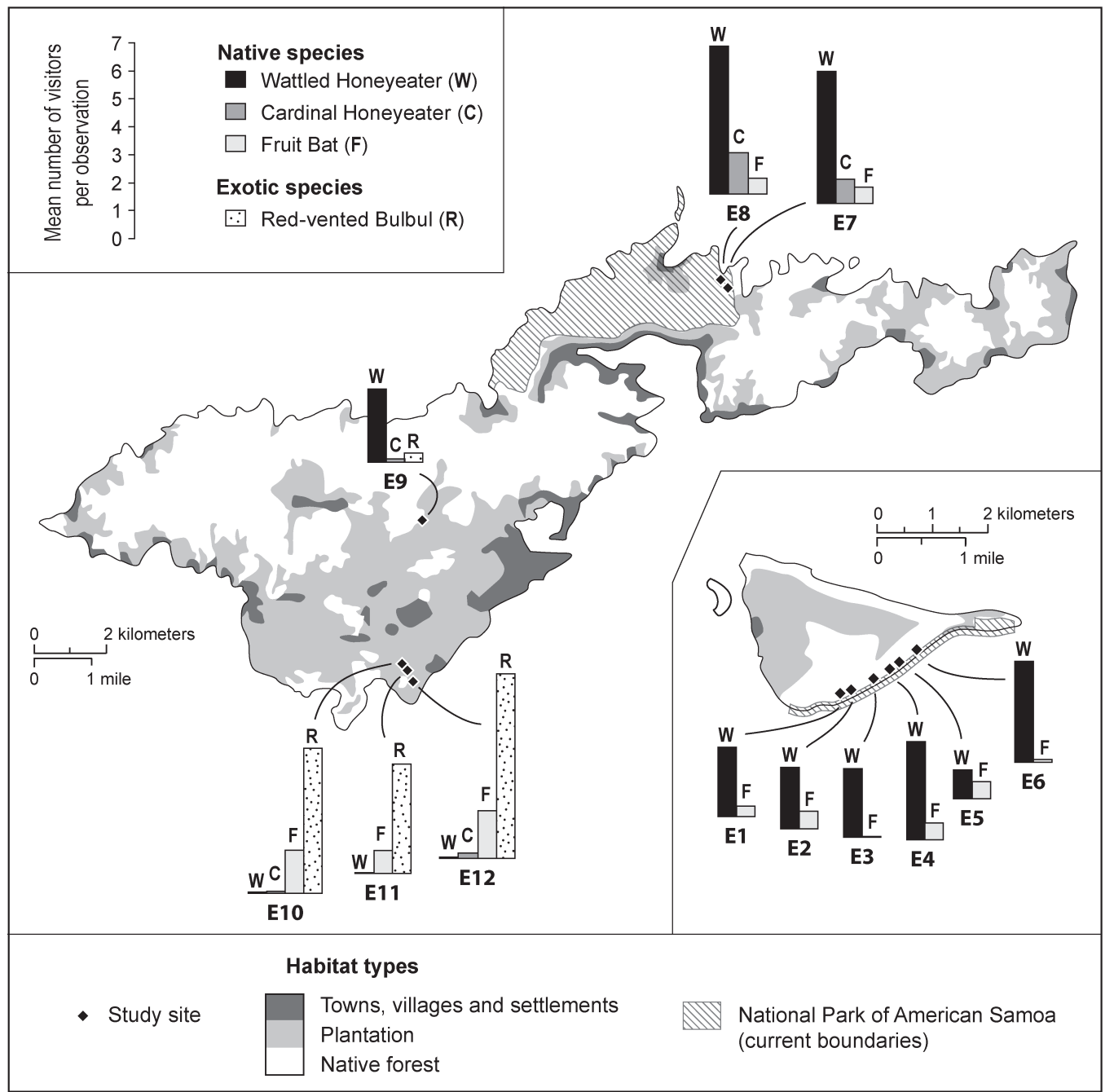

Figure 2. Mean feeding frequencies of birds and bats observed at Erythrina variegata trees on Tutuila and Ofu (inset) islands; habitat types after Whistler (1994). Created by Barbara Trapido-Lurie

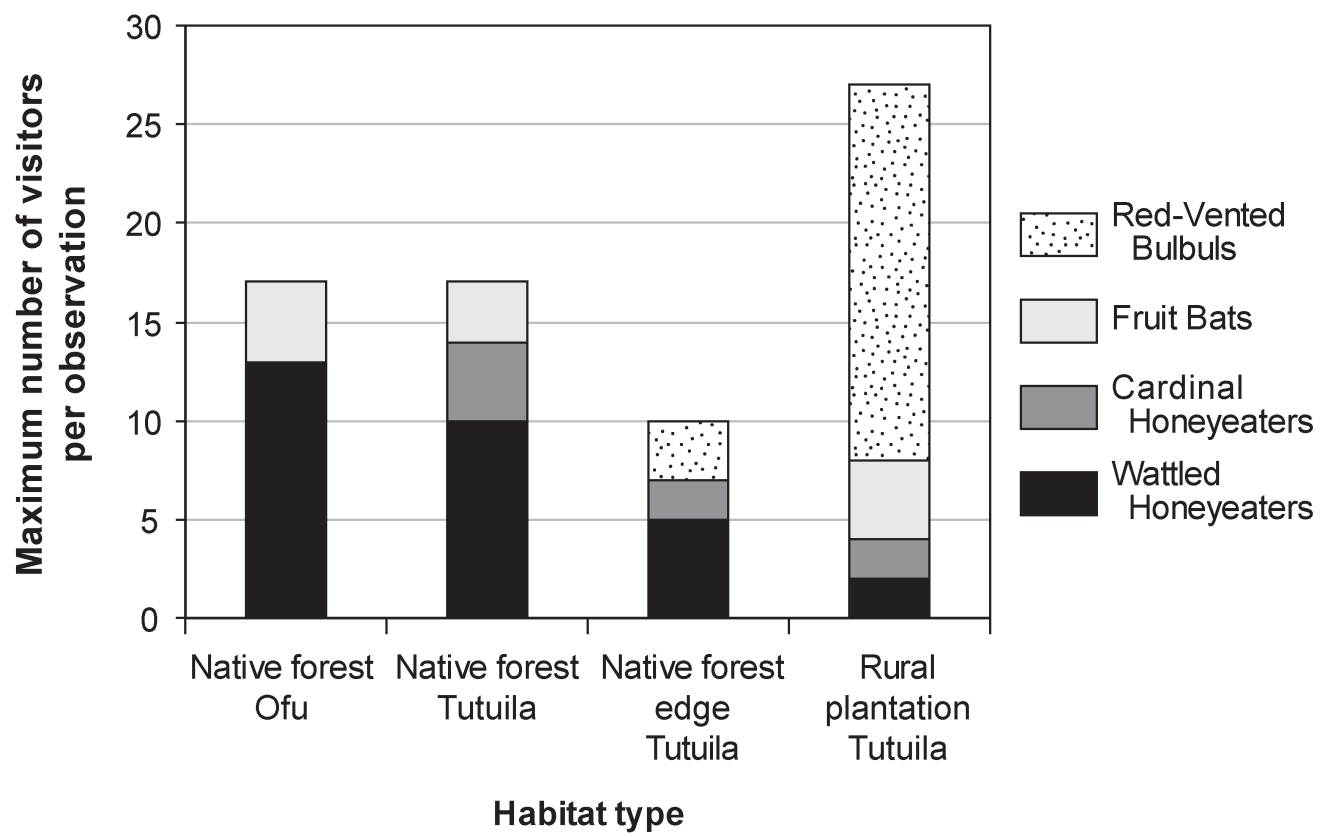

Figure 3. Maximum numbers of birds and bats observed feeding simultaneously at a two-minute interval at Erythrina variegata trees on Tutuila and Ofu islands by focal-tree habitat type. Created by Barbara Trapido-Lurie 


\section{Dysoxylum trees}

We observed Samoan starlings in Dysoxylum trees in Ofu and Tutuila's native forests, and in a rural plantation on Tutuila (Figure 4; Table 4). Pacific pigeons were recorded only in native forest focal trees on Ofu and Tutuila. During most of our observations, these species were perching, not feeding. Similarly, wattled honeyeaters, collared kingfishers (Halcyon chloris) and mynas were observed perching, but not feeding, in Dysoxylum trees on Ofu and Tutuila. Red-vented bulbuls fed at focal Dysoxylum in rural plantations on Tutuila. Samoan starlings were the most frequent visitors to Dysoxylum on both islands. On Tutuila, starling visitation frequency was highest in a rural plantation.

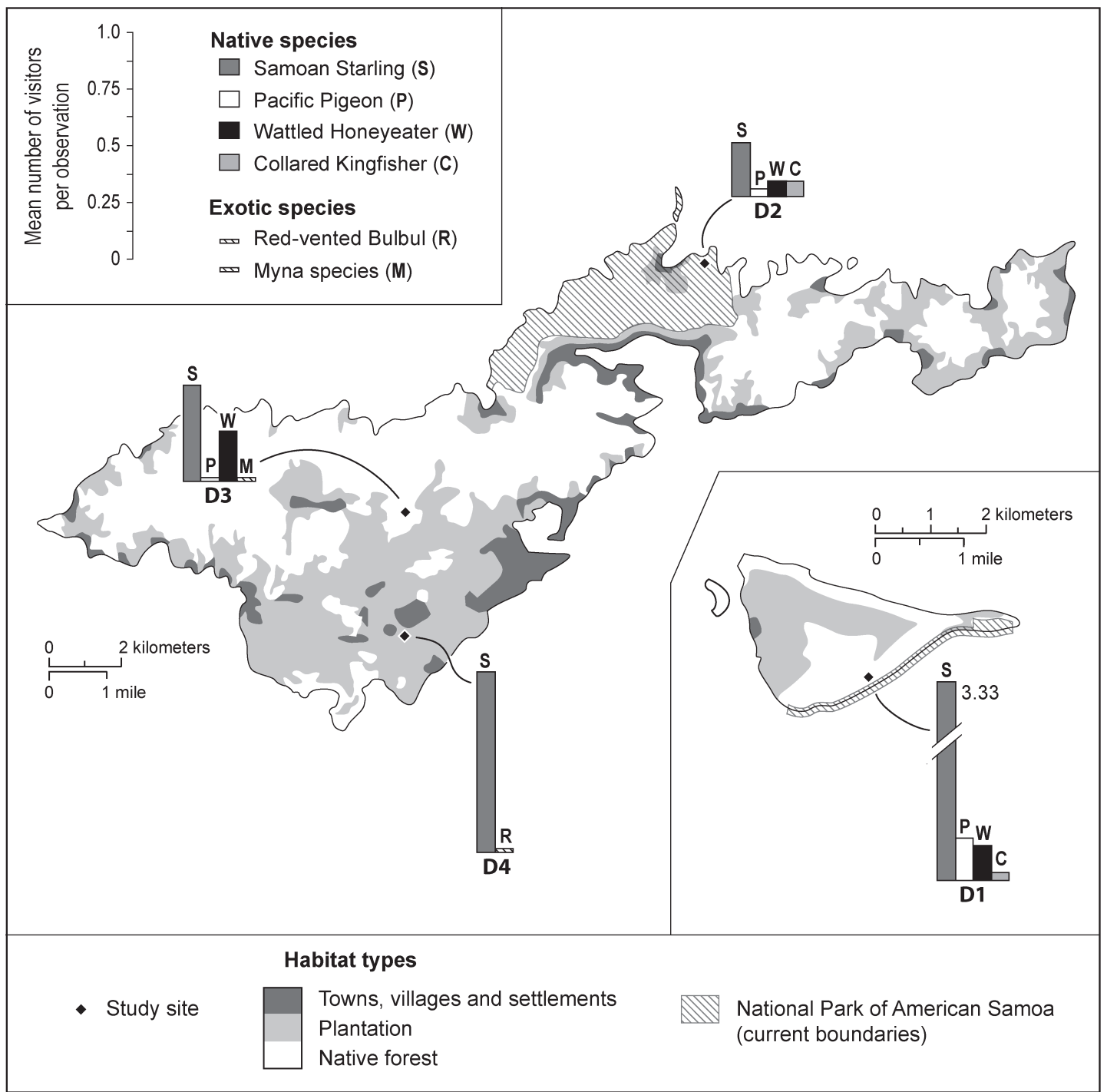

Figure 4. Mean total visitation frequency (feeding and perching) of birds observed at Dysoxylum maoto and Dysoxylum samoensis trees on Tutuila and Ofu islands; habitat types after Whistler (1994). Created by Barbara Trapido-Lurie 
Table 4. Feeding and visitation frequencies at Dysoxylum maoto and Dysoxylum samoensis focal trees on ofu and Tutuila islands, American Samoa. Data are presented as mean (se), indicating average number of visitors and feeders per two-minute interval; HE: honeyeater; se: standard error

\begin{tabular}{|c|c|c|c|c|c|c|c|c|c|}
\hline & \multicolumn{4}{|c|}{ Native feeders } & \multirow{2}{*}{\multicolumn{2}{|c|}{$\begin{array}{l}\text { Exotic feeders } \\
\text { Bulbuls }\end{array}$}} & \multicolumn{3}{|c|}{ Other visitors (no feeding observed) } \\
\hline & \multicolumn{2}{|c|}{ Samoan starlings } & \multicolumn{2}{|c|}{ Pacific pigeons } & & & \multirow{2}{*}{$\begin{array}{l}\text { Wattled HE } \\
\text { Perching }\end{array}$} & \multirow{2}{*}{$\begin{array}{l}\text { Kingfishers } \\
\text { Perching }\end{array}$} & \multirow{2}{*}{$\begin{array}{l}\text { Mynas } \\
\text { Perching }\end{array}$} \\
\hline & Feeding & Perching & Feeding & Perching & Feeding & Perching & & & \\
\hline \multicolumn{10}{|c|}{ Island, Habitat and Tree } \\
\hline \multicolumn{10}{|c|}{ Ofu Island } \\
\hline \multicolumn{10}{|c|}{ Native forest } \\
\hline D1 & $\begin{array}{l}0.38 \\
(0.11)\end{array}$ & $\begin{array}{l}3.33 \\
(0.13)\end{array}$ & $\begin{array}{l}0.02 \\
(0.01)\end{array}$ & $\begin{array}{l}0.19 \\
(0.01)\end{array}$ & 0 & 0 & $0.15(0.04)$ & $0.04(0.02)$ & 0 \\
\hline \multicolumn{10}{|c|}{ Tutuila Island } \\
\hline \multicolumn{10}{|c|}{ Native forest } \\
\hline $\mathrm{D} 2$ & $\begin{array}{l}0.03 \\
(0.02)\end{array}$ & $\begin{array}{l}0.23 \\
(0.06)\end{array}$ & 0 & $\begin{array}{l}0.03 \\
(0.02)\end{array}$ & 0 & 0 & $0.07(0.04)$ & $0.07(0.04)$ & 0 \\
\hline D $3^{1}$ & $\begin{array}{l}0.07 \\
(0.03)\end{array}$ & $\begin{array}{l}0.42 \\
(0.06)\end{array}$ & $0^{1}$ & $\begin{array}{l}0.01 \\
(0.01)\end{array}$ & 0 & 0 & $0.22(0.01)$ & 0 & $\begin{array}{l}0.02 \\
(0.01)\end{array}$ \\
\hline \multicolumn{10}{|c|}{ Rural plantation } \\
\hline D4 & $\begin{array}{c}0.13 \\
(0.05)\end{array}$ & $\begin{array}{l}0.79 \\
(0.11)\end{array}$ & 0 & 0 & $\begin{array}{l}0.02 \\
(0.02)\end{array}$ & $\begin{array}{l}0.05 \\
(0.02)\end{array}$ & $0.01(0.01)$ & 0 & 0 \\
\hline
\end{tabular}

${ }^{1}$ Fruit and fruit peels were observed dropping beneath Pacific pigeons in tree D3, although feeding behaviour was not visible. Two unidentified birds also were observed perching in tree D3. Total mean visitation frequency including feeding and perching is displayed in Figure 4. Tree D1 denotes two adjacent trees with overlapping canopies.

\section{Discussion}

The highest feeding frequency of wattled honeyeaters occurred at trees in relatively undisturbed native forests on both Ofu and Tutuila, in accordance with the reported preference of this species for feeding in native forests (Freifeld 1999; Steadman et al. 1999). In contrast, we recorded honeyeaters feeding rarely and for very brief periods in rural plantations. Large flocks of wattled honeyeaters fed simultaneously for extended periods at focal trees not visited by bulbuls. Watling (2004) notes that wattled honeyeaters attempt to protect preferred nectar sources from bulbuls, sometimes in vain. Our observations show that in rural plantation habitats, red-vented bulbuls fed in and successfully defended Erythrina trees from most feeding attempts by wattled honeyeaters. The wattled honeyeater currently is the most abundant land bird on Tutuila (Freifeld 1999), but continued destruction of native forests may increasingly drive it to forest-edge or plantation habitats where it finds itself at a competitive disadvantage against introduced birds at favoured food sources, such as Erythrina trees.

The highest feeding frequency of cardinal honeyeaters was at Erythrina trees in Tutuila's native forest. Freifeld (1999) suggests that wattled honeyeaters may attempt to exclude cardinal honeyeaters from Erythrina in native-forest habitats. We did not observe inter-specific chases among wattled and cardinal honeyeaters, although an intraspecific chase between two cardinal honeyeaters was recorded at a rural plantation tree. Our data show both cardinal honeyeater and wattled honeyeater feeding frequency increased at trees in native forests, and decreased dramatically in rural plantations, where large numbers of red-vented bulbuls were feeding. As with wattled honeyeaters, we observed red-vented bulbuls chasing cardinal honeyeaters from the trees. Cardinal honeyeaters were recorded feeding at these trees for brief periods between chases. Cardinal honeyeaters were surprisingly uncommon at the forest-edge tree, where we anticipated them in abundance due to the relatively low feeding frequency of red-vented bulbuls, and because studies suggest cardinal honeyeaters prefer edge and village habitats to native forests (Freifeld 1999). However, our forest-edge tree may have offered insufficient 
food resources, as its flowers were dropping during the last day of observations. Feeding frequencies of both birds and fruit bats at Erythrina variegata appeared to vary with changes in the focal trees' flowers. Visitation frequencies decreased noticeably as flowers dropped petals. This occurred over a period of a few days to a week. The process happened more quickly at trees with higher visitation frequencies, suggesting that intensive nectar feeding contributes to floral demise.

Red-vented bulbuls were prolific feeders at trees on rural plantations where they aggressively defended Erythrina flowers from both species of honeyeaters, through aerial chases and vocalisation. Bulbuls were less common visitors to the tree in forest-edge habitat, and they were not observed feeding at any trees in native rainforest. In addition to inserting their beaks into Erythrina flowers, we also observed them eating flowers. Bulbuls outside their native range often are described as limited to human-modified habitats (Freifeld 1999; Eguchi and Amano 2004; Watling 2004; Yap and Sodhi 2004; Peh et al. 2006), however, on Oahu, Hawai i, they have spread into undeveloped areas once used exclusively by native birds (McAllan and Hobcroft 2005), tripling their range in only six years (van Riper et al. 1979; Williams and van Giddings 1984). We observed the greatest frequency of bulbuls in trees on a rural plantation $8 \mathrm{~km}$ from the nearest village. McAllan and Hobcroft (2005) suggest that roads may be one vector for the dispersal of red-vented bulbuls into non-village habitats in Samoa. Perhaps reflecting this tendency, three bulbuls were observed in native forest alongside a road near the small town of Afono. The growth and geographical spread of human population in American Samoa may facilitate expansion of the bulbuls' range, and increase their conflict or competition with native birds.

Fruit bats of both species fed in native-forest trees on Ofu and Tutuila, hanging on branches to feed at flowers, also inserting their mouths into blossoms to lick nectar, and occasionally consuming petals. Fruit bats fed most frequently at Erythrina in rural plantation habitats on Tutuila. Nelson and others (2000a) found that the Samoan fruit bats prefer native foods to agricultural fruits, while the Tongan fruit bats eat both native and agricultural fruits (Banack 1996). The visitation and feeding frequency of fruit bats at Erythrina trees did not change notably with the presence or abundance of exotic or native birds. We observed fruit bats having frequent vocal interactions, and displacing one another from trees or inflorescences. In contrast to birds, bats were not seen pursuing other species. However, we noted very high concentrations of fruit bats and no visible birds at a cluster of Erythrina trees on the edge of a hotel development, suggesting the possibility of inter-species exclusion. Our results may underestimate fruit-bat feeding at Erythrina flowers, as both species also feed at night and, in the case of the Samoan bat, during other daylight hours (Banack 1996; Brooke 2001). Proximity to diverse food sources may affect fruit-bat feeding frequencies at individual Erythrina trees, as both bat species tend to visit numerous different trees for flowers or fruit (Banack 1996). Availability of roost trees also may influence Samoan fruit-bat feeding choices, since they use long-term roosts and small core habitat areas (Brooke 2001). Researchers found Samoan fruit bats roost most frequently in areas with the highest percentage of food-producing trees (Brooke et al. 2000). Brooke (2001) radio-tracked two Samoan fruit bats and found that they foraged over areas between $1.2 \mathrm{~km}^{2}$ and $8.18 \mathrm{~km}^{2}$.

We observed the highest feeding frequency of Samoan starlings at Dysoxylum trees in native forest on Ofu. On Tutuila, our data show most frequent feeding by starlings at a rural plantation tree. Freifeld (1999) suggests that Samoan starlings may be the only native birds that feed in agricultural habitats. Many native foods preferred by starlings, including Dysoxylum, are common in disturbed landscapes and along habitat edges (Whistler 1994; Freifeld 1999). Samoan starlings are key contributors to recolonisation of disturbed areas by native plants, due to their dispersal of a variety of native seeds. 
Pacific pigeons were recorded only at Dysoxylum trees in native rainforest. This supports research indicating that Pacific pigeons avoid human-modified habitats, and are dependent on relatively undisturbed native forests, where they feed exclusively (Freifeld 1999; Franklin and Steadman 2001; Freifeld and Steadman 2001; McConkey et al. 2004b). Pacific pigeon visitation frequency was low for all observed locations. Our data may underestimate feeding and visitation by Pacific pigeons, as the species is notably cryptic, especially near human populations (Freifeld 1999). Current populations of Pacific pigeons have not rebounded from hurricanes and subsequent hunting pressures (Craig et al. 1994a, b; Freifeld 2004), suggesting recovery to past population levels may be unlikely, as more of the native lowland rainforest on Tutuila is lost.

\section{Conclusions}

Our data show feeding frequency differences at individual trees and between trees in broad habitat categories. Native birds fed frequently at focal trees in native forests, but seldom in rural plantations. Native honeyeaters were largely excluded from Erythrina trees where large numbers of exotic red-vented bulbuls were feeding. Native Pacific pigeons were observed feeding only at trees in native forest. The presence of red-vented bulbuls may be an important determinant in feeding patterns of American Samoan native birds at Erythrina variegata trees. Bulbuls aggressively defended Erythrina trees on rural plantations and largely excluded native honeyeaters from feeding, whereas fruit bats fed at Eyrthrina in both native forest and rural plantations, even when large numbers of red-vented bulbuls were present. Similarly, human habitat modifications may affect feeding of native birds at fruiting Dysoxylum trees. Pacific pigeons were not recorded in disturbed habitats, and were observed feeding at Dysoxylum only in native forests. Both Samoan starlings and Pacific pigeons visited and fed at the greatest frequency at Dysoxylum trees in Ofu's native forest. This study underscores the need for more studies on the impacts of America Samoa's invasive birds on native avian and fruit-bat habitat and feeding preferences across a broader range of seasons, food sources and habitat types, as well as the critical role of human land-use and wildlife management policies for the conservation of American Samoa's native fauna.

\section{Acknowledgements}

We are grateful to Suzanne Nelson and Darin Masters for their invaluable help in American Samoa. We thank Peter Craig and the staff of the National Park of American Samoa, Vaoto Lodge, and our families for assistance in American Samoa. The research was funded by two Matthew G. Bailey Scholarships from the School of Geographical Sciences, Arizona State University. We thank Steve Falconer, Taly Drezner, Anthony Brazel and David E. Brown for comments on an early draft of this manuscript, Jon Luly and an anonymous reviewer for helpful suggestions and Barbara Trapido-Lurie for creating the figures.

\section{References}

Altmann, J. 1974. Observational study of behavior: sampling methods. Behavior 69:227-263. Banack, S.A. 1996. Flying foxes, genus Pteropus, in the Samoan Islands: Interactions with forest communities. Unpublished PhD thesis. Berkeley: University of California. 
Banack, S.A. 1998. Diet selection and resource use by flying foxes (genus Pteropus). Ecology 79:1949-1967.

Banack, S.A. and G.S. Grant 2002. Spatial and temporal movement patterns of the flying fox, Pteropus tonganus, in American Samoa. Journal of Wildlife Management 66:1154-1163.

Banko, P.C., P.T. Oboyski, J.W. Slotterback, S.J. Dougill, D.M. Goltz, L. Johnson, M.E. Laut and T.C. Murray 2002. Availability of food resources, distribution of invasive species, and conservation of a Hawaiian bird along a gradient of elevation. Journal of Biogeography 29:789-808.

Blanvillain, C., J.M. Salducci, G. Tutururai and M. Maeura 2003. Impact of introduced birds on the recovery of the Tahiti flycatcher (Pomarea nigra), a critically endangered forest bird of Tahiti. Biological Conservation 109:197-205.

Boinski S. and P.E. Scott 1988. Association of birds with monkeys in Costa Rica. Biotropica 20:136-143.

Brooke, A.P. 2001. Population status and behaviours of the Samoan flying fox (Pteropus samoensis) on Tutuila Island, American Samoa. Journal of Zoology 254:309-319.

Brooke, A.P., C. Solek and A. Tualaulelei 2000. Roosting behavior of colonial and solitary flying foxes in American Samoa (Chiroptera: Pteripodidea). Biotropica 32:338-350.

Cocklin, C. and M. Keen 2000. Urbanization in the Pacific: Environmental change, vulnerability and human security. Environmental Conservation 27:392-403.

Cox, P.A., T. Elmqvist, E.D. Pierson and W.E. Rainey 1991. Flying foxes as strong interactors in South Pacific island ecosystems: A conservation hypothesis. Conservation Biology 5:448-454.

Craig, P., P. Trail and T.E. Morrell 1994a. The decline of fruit bats in American Samoa due to hurricanes and overhunting. Biological Conservation 69:261-266.

Craig, P., T.E. Morrell and K. So' oto 1994b. Subsistence harvest of birds, fruit bats and other game in American Samoa, 1990-1991. Pacific Science 48:344-352.

Dahl, A.L. 1984a. Biogeographical aspects of isolation in the Pacific. Ambio 13:302-305.

Dahl, A.L. 1984b. Oceania's most pressing environmental problems. Ambio 13:296-301.

Eguchi, K. and H.E. Amano 2004. Spread of exotic birds in Japan. Ornithological Science 3:3-11.

Elmqvist, T., W.E. Rainey, E.D. Pierson and P.A. Cox 1994. Effects of tropical cyclones Ofa and Val on the structure of a Samoan lowland rain forest. Biotropica 26:384-391.

Fall, P.L. 2005. Vegetation change in the coastal-lowland rainforest at Avai'o'vuna Swamp, Vava'u, Kingdom of Tonga. Quaternary Research 64:451-459.

Fall, P.L., T.D. Drezner and J. Franklin 2007. Dispersal ecology of the lowland rain forest in the Vava'u island group, Kingdom of Tonga. New Zealand Journal of Botany 45:393-417.

Franklin, J., D.R. Drake, K.R. McConkey, F. Tonga and L.B. Smith 2004. The effects of Cyclone Waka on the structure of lowland tropical rain forest in Vava'u, Tonga. Journal of Tropical Ecology 20:409-420.

Franklin, J. and D.W. Steadman 2001. The potential for conservation of Polynesian birds through habitat mapping and species translocation. Conservation Biology 5:506-521.

Freifeld, H.B. 1999. Habitat relationships of Samoan forest birds on Tutuila Island, American Samoa. Journal of Biogeography 26:1191-1213.

Freifeld, H.B. 2004. Temporal variation in forest bird survey data from Tutuila Island, American Samoa. Pacific Science 58:99-117.

Freifeld, H.B. and D.W. Steadman 2001. Landbirds on offshore islands in Samoa. Journal of Field Ornithology 72:72-85.

Fujita, M.S. and M.D. Tuttle 1991. Flying foxes (Chiroptera: Pteropodidae): Threatened animals of key ecological and economic importance. Conservation Biology 5:455-463. 
Hansen, D.M., J.M. Olesen and C.G. Jones 2002. Trees, birds and bees in Mauritius: Exploitative competition between introduced honey bees and endemic nectarivorous birds. Journal of Biogeography 29:721-734.

Hjerpe, J., H. Hedenås and T. Elmqvist 2001. Tropical rain forest recovery from cyclone damage and fire in Samoa. Biotropica 33:249-259.

Kirika, J.M., N. Farwig and K. Bohning-Gaese 2008. Effects of local disturbance of tropical forests on frugivores and seed removal of a small-seeded Afrotropical tree. Conservation Biology 22:318-328.

Koopman, K.R. and D.W. Steadman 1995. Extinction and biogeography of bats on 'Eua, Kingdom of Tonga. American Museum of Novitates 3125:1-13.

McAllan, I.A.W. and D. Hobcroft 2005. The further spread of introduced birds in Samoa. Notornis 52:16-20.

McConkey, K.R. and D.R. Drake 2002. Extinct pigeons and declining bat populations: are large seeds still being dispersed in the tropical Pacific. In D. Levey, W. Silva, and M. Galetti (eds) Frugivory and seed dispersal: evolutionary and conservation perspectives, pp381395. Wallingford: CAB International.

McConkey, K.R., D.R. Drake, J. Franklin and F. Tonga 2004a. Effects of Cyclone Waka on flying foxes (Pteropus tonganus) in the Vava'u Islands of Tonga. Journal of Tropical Ecology 20:555-561.

McConkey, K.R., H.J. Meehan and D.R. Drake 2004b. Seed dispersal by Pacific pigeons (Ducula pacifica) in Tonga, Western Polynesia. Emu 104:369-376.

Meehan, H.J., K.R. McConkey and D.R. Drake 2002. Potential disruptions to seed dispersal mutualisms in Tonga, Western Polynesia. Journal of Biogeography 29:695-712.

Mickleburgh, S.P., A.M. Hutson and P.A. Racey 1992. Old World fruit bats: An action plan for their conservation. Gland, Switzerland: Chiroptera Specialist Group, Species Survival Commission, IUCN.

Morrell, T.E. and P. Craig 1995. Temporal variation in fruit bats observed during daytime surveys in American Samoa. Wildlife Society Bulletin 23:36-40.

Mueller-Dombois, D. and F.R. Fosberg 1998. Vegetation of the tropical Pacific Islands. New York: Springer-Verlag.

Munoz-Romo, M. 2006. Ethogram and diurnal activities of a colony of Artibeus lituratus (Phyllostomidae: Stenodermatinae). Acta Chiropterologica 8:231-238.

Nelson, S.L., M.A. Miller, E.J. Heske and G.C. Fahey, Jr. 2000a. Nutritional consequences of a change in diet from native to agricultural fruits for the Samoan fruit bat. Ecography 23:393-401.

Nelson, S.L., M.A. Miller, E.J. Heske and G. C. Fahey, Jr. 2000b. Nutritional quality of leaves and unripe fruit consumed as famine foods by the flying foxes of Samoa. Pacific Science 54:301-312.

Nelson, S.L., T.H. Kunz and S.R. Humphrey 2005. Folivory in fruit bats: Leaves provide a natural source of calcium. Journal of Chemical Ecology 31:1683-1691.

Ochoa-Acuña, H. and T. H. Kunz 1999. Thermoregulatory behavior in the small island flying fox, Pteropus hypomelanus (Chiroptera:Pteropodidae). Journal of Thermal Biology 24:15-20.

Peh, K.S-H., N.S. Sodhi, J. de Jong, C.H. Sekercioglu, C.A.-M.Yap and S.L.-H. Lim 2006. Conservation value of degraded habitats for forest birds in southern Peninsular Malaysia. Diversity and Distributions 12:572-581.

Pierson, E.D, T. Elmqvist, W.E. Rainey and P.A. Cox 1996. Effects of tropical cyclonic storms on flying fox populations on the South Pacific islands of Samoa. Conservation Biology 10:438-451.

Pitter, E. and M.B. Christiansen 1997. Behavior of individuals and social interactions of the red-fronted macaw Ara rubrogenys in the wild during the midday rest. Ornitologia Neotropical 8:133-143. 
Rainey, W.E., E.D. Pierson, T. Elmqvist and P.A. Cox 1995. The role of flying foxes (Pteropodidae) in oceanic island ecosystems of the Pacific. Symposia of the Zoological Society of London 67:47-62.

Richardson, D.M., P. Pysek, M. Rejmanek, M.G. Barbour, D. Panetta and C.J. West 2000. Naturalization and invasion of alien plants: concepts and definitions. Diversity and Distributions 6:93-107.

Rinke, D.R. 1986. The status of wildlife in Tonga. Oryx 20:146-151.

Steadman, D.W. 1993. Biogeography of Tongan birds before and after human impact. Proceedings of the National Academy of Sciences, U.S.A. 90:818-822.

Steadman, D.W. 1995. Prehistoric extinctions of Pacific island birds. Science 267:1123-1131.

Steadman, D.W. 2006. Extinction and biogeography of tropical Pacific birds. Chicago: University of Chicago Press.

Steadman, D.W. and H.B. Freifeld 1999. The food habits of Polynesian pigeons and doves: A systematic and biogeographic review. Ecotropica 5:13-33.

Steadman, D.W., J. Franklin, D.R. Drake, H.B. Freifeld, L.A. Bolick, D.S. Smith and T.J. Motley 1999. Conservation status of forests and vertebrate communities in the Vava'u Island Group, Tonga. Pacific Conservation Biology 5:191-207.

Steadman, D.W. and P.A. Martin 2003. The late Quaternary extinction and future resurrection of birds on Pacific islands. Earth Science Reviews 61:133-147.

Sun, C. and T.C. Moermond 1997. Foraging ecology of three sympatric turacos in a montane forest in Rwanda. Auk 114:396-404.

Thibault, J.C., J.L. Martin, A. Penloup and J.Y. Meyer 2002. Understanding the decline and extinction of monarchs (Aves) in Polynesian Islands. Biological Conservation 108:161-174.

Thorsen, M., R. Shorten, R. Lucking and V. Lucking 2000. Norway rats (Rattus norvegicus) on Fregate Island, Seychelles: The invasion; subsequent eradication attempts and implications for the island's fauna. Biological Conservation 96:133-138.

Tirado Herrera, E.R., T. Franke, C. Knogge, J. Skrabal and E.W. Heymann 2003. Flower and Fruit Visitors of Marcgravia longifolia in Amazonian Peru. Plant Biology 5:210-214.

United States Census Bureau 2001. Census 2000 Population Counts for American Samoa. United States Census Bureau Public Information Office. http://www.census.gov/ census2000/americansamoa.html.

United States Naval Observatory 2007. Complete Sun and Moon Data for One Day. USNO website. http://aa.usno.navy.mil/data/docs/RS_OneDay.php.

Utzurrum, R.C.B. 2002. Flying foxes (fruit bats). In P. Craig (ed) Natural history guide to American Samoa: A collection of articles, pp34-36. Pago Pago: National Park of American Samoa and Department of Marine and Wildlife Resources.

van Riper C. III, S.G. van Riper and A.J. Berger 1979. The red-whiskered bulbul in Hawaii. Wilson Bulletin 91:323-328.

Watling, D. 2004. A Guide to the Birds of Fiji and Western Polynesia. Suva: Environmental Consultants Ltd.

Webb, E.L., B.J. Stanfield and M.L. Jensen 1999. Effects of topography on rainforest tree community structure and diversity in American Samoa, and its implications for frugivore and nectivore populations. Journal of Biogeography 26:887-897.

Western Regional Climate Center 2005. Pago Pago, American Samoa: Normals, means, and extremes. Western Regional Climate Center. http://www.wrcc.dri.edu/cgi-bin/clilcd. pl?pi61705.

Whistler, W.A. 1992. Flowers of the Pacific Island seashore: a guide to the littoral plants of Hawaii, Tahiti, Samoa, Tonga, Cook Islands, Fiji, and Micronesia. Honolulu: Isle Botanica.

Whistler, W.A. 1994. Botanical inventory of the proposed Tutuila and Ofu units of the National Park of American Samoa. Cooperative National Park Resources Studies Unit Technical Report 87. Honolulu: University of Hawaii at Manoa, Department of Botany. 
Whistler, W.A. 2002. The Samoan Rainforest: a guide to the vegetation of the Samoan archipelago. Honolulu: Isla Botanica.

Wiles, G.J., J. Engbring and D. Otobed 1997. Abundance, biology, and human exploitation of bats in the Palau Islands. Journal of Zoology 241:203-227.

Williams, R.N. and L. van Giddings 1984. Differential range expansion and populations growth of bulbuls in Hawaii. Wilson Bulletin 96:647-655.

World Gazetteer 2006. American Samoa: largest cities and towns and statistics of their population. World Gazetteer online. http://www.world-gazetteer.com

Yap, C.A.M. and N.S. Sodhi 2004. Southeast Asian invasive birds: Ecology, impact and management. Ornithological Science 3:57-67. 